\title{
Association between the spread of circulating tumor cells and breast cancer subtypes
}

\author{
Xiaowei Qi, Xinhua Yang, Linjun Fan, Yi Zhang, Fan Zhang and Jun Jiang* \\ See related research by Fehm et al., http://breast-cancer-research.com/content/11/4/R59
}

We read with great interest the recent publication by Fehm and coworkers [1] about the association between the spread of circulating tumor cells (CTCs) and breast cancer subtypes. The authors observed that the highest CTC positivity rate was obtained in triple-negative patients followed by those with estrogen receptor (ER)positive and/or progesterone receptor (PR)-positive tumors, while no CTCs could be detected in the human epidermal growth factor receptor 2 (HER2)-positive subtype group. However, another study [2] showed contradictory results, indicating that HER2 was the only primary tumor characteristic that correlated with the presence of CTCs, while ER and PR status were not association with their presence.

To clarify the correlation between CTCs and breast cancer subtypes, a total of 156 operable breast cancer patients admitted to our hospital were enrolled. This study was approved by the regional ethics committee. Written informed consent was obtained from all participating patients. Mononuclear cell enrichment and CTC detection were done as previously described [3]. The expression of ER, PR and HER2 in primary tumors was routinely detected.

Results showed that the overall positive rate of CTCs in operable breast cancer patients was $32.1 \%$ (50 out of 156). There existed significant differences in the positive rate of CTCs between patients at different pTNM stages $(P=0.0219)$ and between those with different immunohistochemical subtypes $(P=0.0003)$. Further analysis revealed that the positive rate of CTCs in the HER2positive and triple-negative subtypes was significantly higher than that of the luminal subtype $(P=0.0034$ and 0.0003 , respectively). In subgroup analysis by pTNM stage, significant differences in the positive rate of CTCs between patients with different breast cancer subtypes

*Correspondence: jcbd@medmail.com.cn

Breast Disease Center, Southwest Hospital, Third Military Medical University, Gaotanyan Street 29, Chongqing, 400038, China
Table 1. Correlation of CTCs and immunohistochemical subtypes of breast cancer in subgroup analysis by pTNM stage

\begin{tabular}{|c|c|c|c|c|c|c|c|}
\hline \multirow[b]{2}{*}{$\begin{array}{l}\text { pTNM } \\
\text { stage }\end{array}$} & \multicolumn{2}{|c|}{$\begin{array}{l}\text { Luminal } \\
\text { subtype }\end{array}$} & \multicolumn{2}{|c|}{$\begin{array}{l}\text { HER2-positive } \\
\text { subtype }\end{array}$} & \multicolumn{2}{|c|}{$\begin{array}{c}\text { Triple-negative } \\
\text { subtype }\end{array}$} & \multirow[b]{2}{*}{$P^{a}$} \\
\hline & $\begin{array}{c}\text { CTC- } \\
\text { positive } \\
\text { cases }\end{array}$ & $\begin{array}{l}\text { Total } \\
\text { cases }\end{array}$ & $\begin{array}{c}\text { CTC- } \\
\text { positive } \\
\text { cases }\end{array}$ & $\begin{array}{l}\text { Total } \\
\text { cases }\end{array}$ & $\begin{array}{c}\text { CTC- } \\
\text { positive } \\
\text { cases }\end{array}$ & $\begin{array}{l}\text { Total } \\
\text { cases }\end{array}$ & \\
\hline r & 2 & 23 & 1 & 6 & 4 & 10 & $0.0207^{b}$ \\
\hline$\|$ & 7 & 38 & 5 & 10 & 8 & 18 & 0.0478 \\
\hline III & 8 & 28 & 6 & 9 & 9 & 14 & 0.0324 \\
\hline
\end{tabular}

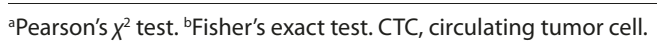

were identified at stages I $(P=0.0207)$, II $(P=0.0478)$ and III $(P=0.0324)$ (Table 1$)$, further supporting that the presence of CTCs was associated with the HER2-positive and triple-negative subtypes.

In the present study, the presence of CTCs was more frequently found in patients with HER2-positive and triple-negative subtypes than the luminal subtype, which might be ascribed to primary tumors of the former two subtypes being more aggressive histologically and having increased potential to be invasive, to migrate and to metastasize. In addition, recent research has suggested that the epithelial-mesenchymal transition plays a critical role in cancer progression, which could endow cancer cells with aggressive and stem cell-like properties, and promote the dissemination of CTCs from the primary site to the circulation [4]. Most importantly, it has been shown that CTCs could express epithelial-mesenchymal transition and/or cancer stem cell markers, which would support the hypothesis derived from the clinical data that CTCs are closely associated with distant metastasis in breast cancer patients [5]. Therefore, all these observations further support the need to clarify the correlation of primary tumor characteristics and CTCs in breast cancer patients.

In conclusion, our study suggests that the spread of CTCs was correlated with the HER2-positive and triplenegative subtypes in breast cancer patients. Identifying 
patients at higher risk of harboring CTCs would be helpful for the purpose of establishing the clinical values of CTCs as well as better evaluating the prognosis of breast cancer patients.

\section{Abbreviations}

$\mathrm{CTC}=$ circulating tumor cell; $\mathrm{ER}=$ estrogen receptor; $\mathrm{HER}=$ human epidermal growth factor receptor; $\mathrm{PR}=$ progesterone receptor

\section{Competing interests}

The authors declare that they have no competing interests.

\section{Acknowledgments}

We thank Mrs Bin Zhao, from Breast Disease Center, Southwest Hospital, Third Military Medical University, Chongqing, China, for language editing of the manuscript. This work was not supported by any funds.

Published: 17 June 2010

\section{References}

1. Fehm T, Hoffmann O, Aktas B, Becker S, Solomayer EF, Wallwiener D, Kimmig $\mathrm{R}$, Kasimir-Bauer S: Detection and characterization of circulating tumor cells in blood of primary breast cancer patients by RT-PCR and comparison to status of bone marrow disseminated cells. Breast Cancer Res 2009, 11:R59.

2. Lang JE, Mosalpuria K, Cristofanilli M, Krishnamurthy S, Reuben J, Singh B, Bedrosian I, Meric-Bernstam F, Lucci A: HER2 status predicts the presence of circulating tumor cells in patients with operable breast cancer. Breast Cancer Res Treat 2009, 113:501-507.

3. Bidard FC, Vincent-Salomon A, Sigal-Zafrani B, Diéras V, Mathiot C, Mignot L, Thiery JP, Sastre-Garau X, Pierga JY: Prognosis of women with stage IV breast cancer depends on detection of circulating tumor cells rather than disseminated tumor cells. Ann Oncol 2008, 19:496-500.

4. Polyak K, Weinberg RA: Transitions between epithelial and mesenchymal states: acquisition of malignant and stem cell traits. Nat Rev Cancer 2009, 9:265-273

5. Cristofanilli M, Braun S: Circulating tumor cells revisited. JAMA 2010, 303:1092-1093.

doi: $10.1186 /$ bcr2582

Cite this article as: Qi X, et al:: Association between the spread of circulating tumor cells and breast cancer subtypes. Breast Cancer Research 2010, 12:402. 